\title{
University of California forms company to develop technology from its laboratories
}

San Francisco. Seed money from the University of California (UC) would fund startup companies based on faculty inventions under a plan to bolster projects languishing between government funding and commercial development. A new, for-profit Technology Development Corporation, of which the university would own 51 per cent, would also pay to develop ideas from campus and

\section{UC pins its hopes on patents}

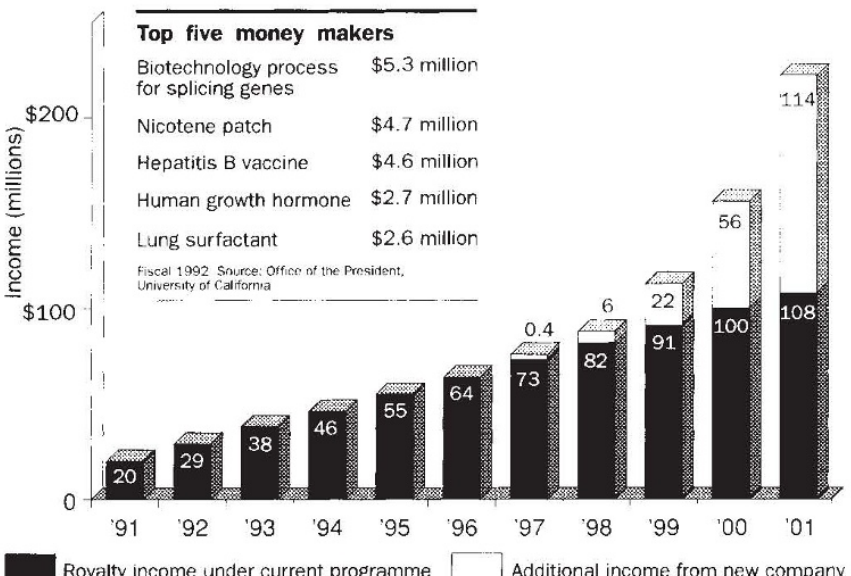

Figures estimated for 1993-2001.

government laboratories into prototypes that outside companies could license.

The university hopes to raise $\$ 100$ million from established companies for the development of technology contributed by the university. UC also hopes to persuade the state to turn over its share of royalty income to help fund the venture, which it expects will cost $\$ 2$ million a year to operate. Next year, it hopes to spend $\$ 2.5$ million on development projects on campus or in government laboratories and $\$ 500,000$ on two startup companies.

The university helped to give birth to the \$6-billion biotechnology industry through the original technique for splicing genes, for which it shares a patent with Stanford University. Its inventions generate more royalty income than any other US university, some $\$ 29$ million in fiscal year 1992 alone (see above).

Jack W. Peltason, UC president, outlined the programme before the university's governing body on 10 December, saying that the goal is to harness faculty brain power to stimulate economic growth and create jobs for California. He estimated that it could generate $\$ 222$ million in gross royalty income by the year 2001. The money would provide a much-needed boost to the cashstrapped UC system, although only about one- third of the total would go into university coffers, with the rest earmarked for inventors and to pay fees and lawyers.

UC has more than 1,000 inventions looking for companies, said Carl Wootten, director of the UC Systemwide Office of Technology Transfer. He estimated that only about half are far enough along to interest industry.

Some projects would continue in on-campus laboratories or move to the federally funded Los Alamos, Livermore and Lawrence Berkelcy Laboratories. A sterling few would merit startup financing from the development company, in tandem with standard venture capitalists willing to share the risk. The university would own part of the companies and share royalties with its venture-capital partners.

The new company would help to make university inventions more attractive as well as generate revenue for the UC system, Wootten said. He believes the university could have reaped another $\$ 50$ million from previous inventions if it had asked for equity in the start-up licensees.

University officials will try to persuade the state to turn over its share of royalty income - 25 percent after expenses and payments to inventors - to pay for operations. Additional money would come from selling stock to long-term investors such as major corporations and retirement systems.

The development company would not fund projects invented outside UC, university officials said, even though outside investors would be participating. And, be cause the university holds the patent to all campus inventions, faculty members would have to bring their inventions first to the UC technology transfer office.

Industry observers are withholding judgement on the proposal, which the university hopes to implement in 1993. Gary Hooper, vice president of business development at Cygnus Therapeutic Systems in Redwood City. California, expressed concern about potential restrictions from outside investors and emphasized the importance of scientists setting their own research agendas.

Similar on-campus funding mechanisms have grown more popular in recent years.
The University of Chicago has started nine companies to develop faculty inventions through its own \$9-million seed venture capital fund. The fund is restricted to university ventures but still provides investors with the chance to invest early in promising new companies, said Robert Nelsen, manager of its not-for-profit parent.

Johns Hopkins has operated a for-profit arm, called Triad Investors Corporation, that provides "bridge" funding for inventions. The company is not limited to supporting university inventions.

Massachusetts Institute of Technology, the leader in university patenting and licensing with about two licences issued a week, owns stock in many licensees, but limits its involvement 1020 per cent or less. It does not finance start-up companies for fear of appearing to be profiting from governmentfunded research.

Sally Lehrman

\section{Germany get price break from CERN}

Munich. Germany has reached an agreement with CERN (the European Laboratory for Particle Physics) to reduce its contribution by SFr25 million (US $\$ 18$ million) for three years because of the high cost of reunification.

At its December meeting, CERN announced that it would give Germany a rebate of 10 per cent on past contributions in recognition of "special circumstances", a reference to its having allowed other former communist countries to join CERN on the cheap. CERN officials wanted to avoid offering Germany a straightforward discount on fees, contrary to its rules, for fear of other countries asking for a similar reprieve.

Half of the shortfall in CERN's annual budget of SFr950 million will be made up by holding increases in salary and material costs to 2.4 per cent instead of the 3.6 per cent that would match inflation. The rest will be made up by general economy measures in the laboratory. There will be no staff redundancies.

Hermann Strub, head of the German delegation to CERN, said that taking on the 18 million citizens of the former East Germany raised Germany's contribution -- determined by a complex algorithm that depends primarily on gross national product - close to the limit of 25 per cent of its budget that CERN can receive from one country. At the same time, Strub emphasized Germany's full commitment to CERN, in particular the Large Hadron Collider (LHC) planned for later in the decade.

Alison Abbott 